\title{
THE EFFECT OF QUALITY OF SERVICE AND CORPORATE IMAGE ON PURCHASING DECISIONS
}

\author{
Abdul Khoir \\ Universitas Pamulang \\ dosen02490@unpam.ac.id
}

\begin{abstract}
This study aims to determine the effect of service quality and corporate image on purchasing decisions at Alfamart South Tangerang Hospital. The method used is explanatory research with analytical techniques using statistical analysis with regression testing, correlation, determination, and hypothesis testing. The results of this study the quality of service significantly influence purchasing decisions by $40.3 \%$, the hypothesis test obtained t count $>t$ table or (7.967> 1.986). The company's image has a significant effect on purchasing decisions by $37.2 \%$, the hypothesis test is obtained $t$ count $>t$ table or (7.466>1.986). Service quality and corporate image simultaneously have a significant effect on purchasing decisions with a regression equation $Y=11,931+0,380 \mathrm{X} 1+$ $0,332 \times 2$ and the contribution of influence is $48.7 \%$, the hypothesis test is obtained $F$ count> F table or $(44,091>2,700)$.
\end{abstract}

Keywords: Service Quality, Company Image, Purchase Decision

\section{INTRODUCTION}

At the present competition in the business world is very tight, which requires companies to be able to be fast and appropriate in dealing with competition in a business environment that is moving very dynamic and full of uncertainty (Pujadi, 2010). Therefore, every company is required to compete competitively in terms of creating and retaining loyal buyers. Every company is required to create a good and integrated competitive strategy because the competition is the key to the success or failure of a company. Increased intensity of competition from competitors requires companies to always pay attention to the needs and desires of consumers and try to meet consumer expectations by providing more satisfying services than those carried out by competitors. Thus, only quality companies can compete and dominate the market. Also, many businesses have emerged, both small and large companies, which have an impact on the intense competition between companies, especially competition from similar companies. This causes companies that apply marketing concepts to need to pay close attention to consumer behavior and factors - factors that influence purchasing decisions in the marketing efforts of a product that is carried out. That is because, in the marketing concept, one way to achieve company goals is to know what the needs and desires of consumers or target markets are and to provide the expected satisfaction more effectively and efficiently than competitors.

Simamora (2012) image is a perception that is relatively consistent in the long run (ending perception). Brands will help buyers in various ways in which brands will help consumers to identify products/services so they can feel the benefits, and brands will explain the quality of products/services to buyers. Kotler \& Amstrong (2016) convey that brand essence is a seller's promise that consistently provides certain displays, benefits, and services to consumers. Thus, in customer value and the company's ability to innovate or have a renewable product variant design when viewed from marketing performance in the same form but in different systems, it will produce different marketing performance as well.

One that is considered quite crowded in the increasingly fierce competition in the retail industry. Retail is a business that sells products/merchandise for household needs, including daily necessities that 
use a self-service system (consumers take the goods/products themselves without a salesperson serving). The retail industry in Indonesia can be divided into 2 major groups, namely Traditional Retail, and Modern Retail. Modern retail is a development of traditional retail. This retail format emerged and developed along with the development of the economy, technology, and lifestyle of the people which made people demand more convenience in shopping.

Minimarket is a type of retail business that is growing rapidly today that sells daily necessities and offers convenience because of its location or location that is reachable and close to consumers and prioritizes practicality and speed that is supported from the area of stores or outlets that are not too large so that consumers shopping with a not too long time. Another advantage of shopping at the convenience store is the safe and comfortable atmosphere of shopping, no difficulty choosing the items needed, the quality of goods is more guaranteed when compared to shopping at traditional markets, the price of goods is certain so that it does not need to be negotiable and can shop for various purposes in one place thus saving time and effort.

In Indonesia, there are many minimarket brands including Circle $\mathrm{K}$, Starmart, Alfamart, Indomaret, and Alfamidi. The minimarket competition in Indonesia is very tight and can be seen from the competition between the two big mini-brand retail brands, namely Indomaret and Alfamart, competition between Indomaret and Alfamart is very tight.

Alfamart is owned by PT. Sumber Alfaria Trijaya (SAT) as one of the companies in the retail industry in the form of a minimarket and includes a national company engaged in general trading and retail services that provide basic needs and daily necessities. All efforts in improving the quality of service carried out by Alfamart to be able to compete with Indomaret include strategic locations, in various regions and easily accessible and always close to Indomaret, a clean and comfortable place, Alfamart strives to provide the best quality service for its customers.

Purchasing decisions are the final stages of the decision-making process until the consumer buys the product or service (Sangadji, 2013). Alfamart has the largest presence in almost all corners of major cities and remote areas. In this study, the authors chose to use data from Alfamart South Tangerang Hospital. This is because the existence of Alfamart South Tangerang Hospital is considered strategic. After all, it is close to health services, namely the South Tangerang Emergency Unit Hospital (South Tangerang District Hospital).

Formulation of the problem: (1) Is there a partial effect between service quality on purchasing decisions at Alfamart South Tangerang Hospital; (2) Is there a partial effect between the company's image on purchasing decisions at Alfamart Tangerang South Hospital; (3) Is there a simultaneous influence between service quality and company image on purchasing decisions at Alfamart South Tangerang Hospital.

Research purposes: (1) To determine the partial effect between service quality on purchasing decisions at Alfamart RSU South Tangerang; (2) To find out partial influence between company image on purchasing decisions at Alfamart South Tangerang Hospital; (3) To determine the simultaneous effect between service quality and company image on purchasing decisions at Alfamart South Tangerang Hospital.

According to Tjiptono (2017) states that Service quality is the expected level of excellence and control over the level of excellence to meet customer desires. Another definition of service quality according to Wyckof in Lovelock cited by Tjiptono (2017) is the expected level of excellence and control over excellence to meet customer 
desires. Meanwhile, according to Parasuraman in Lupiyoadi (2017) that service quality is how far the difference between reality and customer expectations for the service they receive.

Corporate Image is defined as the perception of a company that is reflected in the associations contained in the consumer's memory. According to Kotler \& Keller (2017) states the company's image is related to the physical and attributes associated with the company such as names, buildings, products/services, to influence the quality that is communicated by everyone to be interested in the company. Furthermore, Kotler \& Keller (2017) said that Image illustrates the overall impression made public about the company and its products. Image is influenced by many factors outside the company's control

The purchase decision is one of the stages in the purchase decision process before post-purchase behavior. In entering the stage of the previous purchase decision the consumer is faced with several choices so that at this stage the consumer will take action to decide to buy the product based on the specified choice.

Purchasing decisions are part of consumer behavior that is the study of how individuals, groups, and organizations choose, buy, use, and how goods, services, ideas or experiences to satisfy their needs and desires (Kotler and Amstrong, 2016).

\section{METHODS}

The population in this study amounted to 96 Alfamart South Tangerang Hospital. The sampling technique in this study is saturated sampling, where all members of the population are sampled. Thus the sample in this study amounted to 96 respondents. The type of research used is associative, where the aim is to determine the effect of independent variables on both partial and simultaneous dependent variables. In analyzing the data used the instrument test, classical assumption test, regression, coefficient of determination, and hypothesis testing.

\section{RESULTS AND DISCUSSION Descriptive Analysis}

This test used to determine the minimum and maximum scores, mean scores, and standard deviations of each variable. The results are as follows:

Table 1. Results of Descriptive Statistics Analysis

\begin{tabular}{llllll}
\hline & D & Minimum & Maximum & Mean & Std. Deviation \\
\hline Quality of service (X1) & 96 & 32 & 48 & 38.31 & 3.809 \\
Company Image (X2) & 96 & 30 & 45 & 38.31 & 3.728 \\
Purchase Decision (Y) & 96 & 33 & 46 & 39.20 & 3.439 \\
Valid N (listwise) & 96 & & & & \\
\hline
\end{tabular}

Source: processed data (2020)

Quality of service obtained a minimum variance of 32 and a maximum variance of 48 with a mean score of 3.83 with a standard deviation of 3.809. The company image obtained a minimum variance of 30 and a maximum variance of 45 with a mean score of 3.83 with a standard deviation of 3.728 . The purchase decision obtained a minimum variance of 33 and a maximum variance of 46 with a mean score of 3.92 with a standard deviation of 3.439 .

\section{Verification Analysis.}

This analysis is intended to determine the effect of independent 
variables on the dependent variable. The test results are as follows:
Multiple Linear Regression Analysis

This regression test is intended to determine changes in the dependent variable if the independent variable changes. The test results are as follows:

Table 2. Results of Multiple Linear Regression Testing

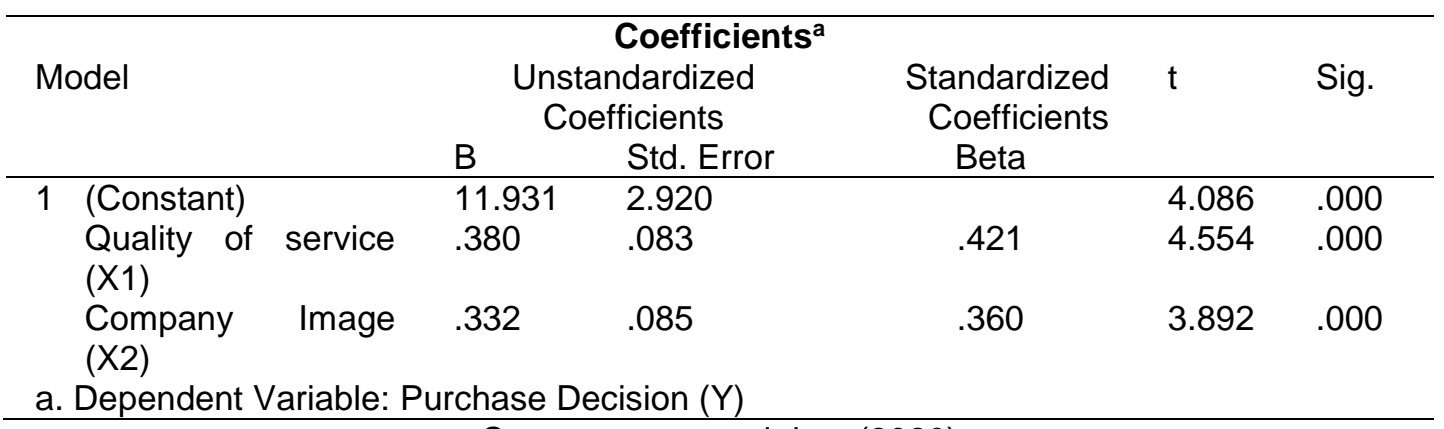

Source: processed data (2020)

Based on the test results in the above table, the regression equation $\mathrm{Y}=$ $11.931+0.380 \times 1+0.332 \times 2$ is obtained. From the equation explained as follows:

A constant of 11,931 means that if there is no service quality and company image, then there is a purchase decision value of 11,931 points. Service quality regression coefficient of 0.380 , this number is positive, meaning that every time there is an increase in service quality by 0.380 , the purchasing decision will also increase by 0.380 points. The regression coefficient of the company's image of 0.332 , this number is positive, meaning that every time there is an increase in the company's image of 0.332 , the purchasing decision will also increase by 0.332 points.

\section{Correlation Coefficient Analysis}

Correlation coefficient analysis is intended to determine the degree of relationship strength of the independent variables on the dependent variable either partially or simultaneously. The test results are as follows:

\section{Table 3. Correlation Coefficient Testing Results Quality of Service Against the purchase} decision

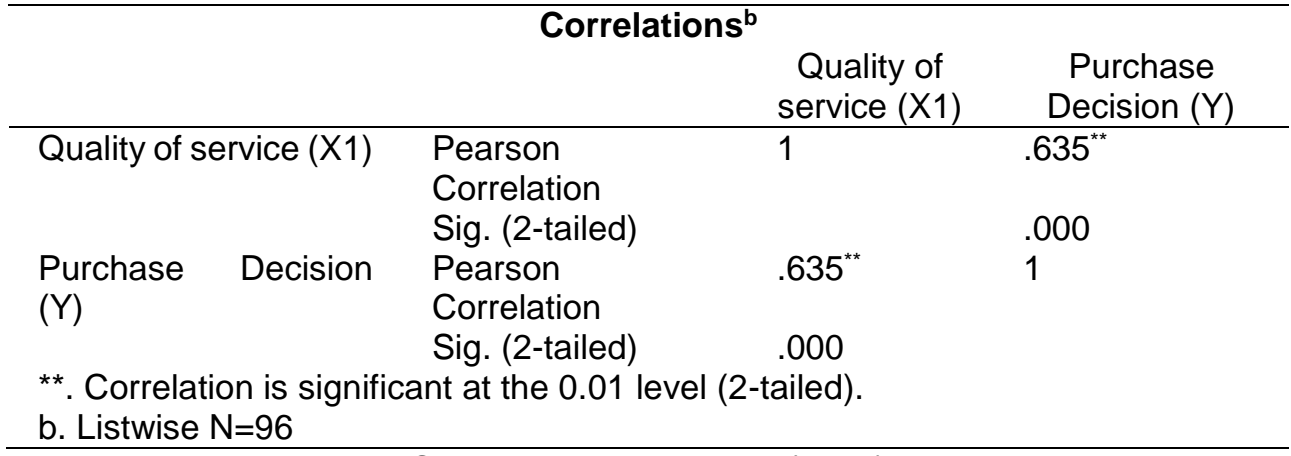

Source: processed data (2020)

Based on the test results obtained a correlation value of 0.635 means that service quality has a strong relationship with purchasing decisions. 
Table 4. Correlation Coefficient Testing Results Corporate Image Against purchasing decisions

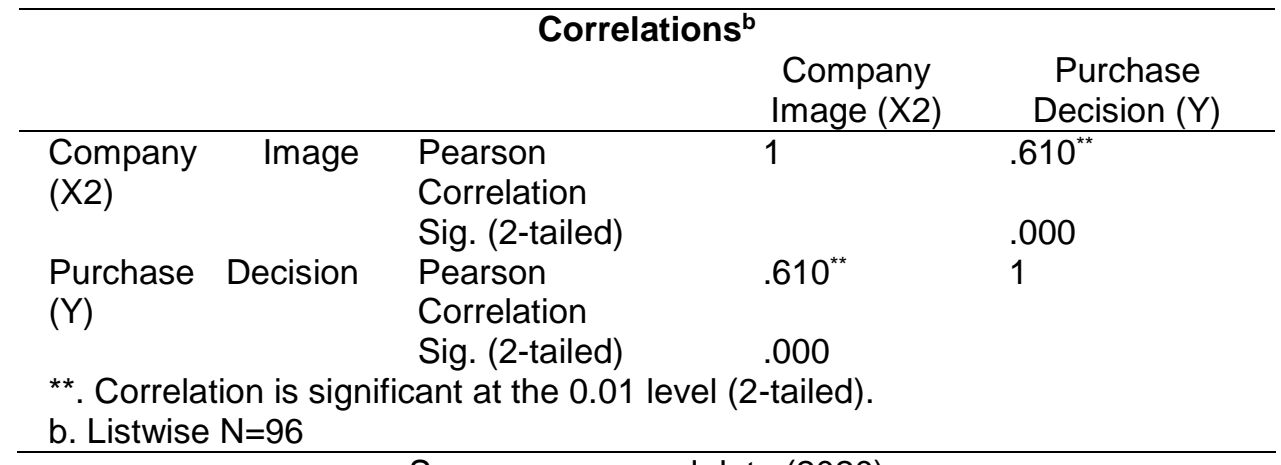

Source: processed data (2020)

Based on the test results obtained a correlation value of 0.610 means that the company's image has a strong relationship with purchasing decisions

Table 5. Results of Correlation Coefficient Testing Simultaneous Service Quality and Corporate Image Against Purchasing Decisions

\begin{tabular}{|c|c|c|c|c|}
\hline \multicolumn{5}{|c|}{ Model Summary } \\
\hline Model & $\mathrm{R}$ & R Square & $\begin{array}{l}\text { Adjusted R } \\
\text { Square }\end{array}$ & $\begin{array}{c}\text { Std. Error of the } \\
\text { Estimate }\end{array}$ \\
\hline $\begin{array}{l}1 \\
\text { a. Pred }\end{array}$ & $\begin{array}{r}.698^{a} \\
\text { Consta } \\
\end{array}$ & $\begin{array}{l}.487 \\
\text { y Image(X2) }\end{array}$ & $\begin{array}{l}.476 \\
\text { ality of servic }\end{array}$ & $\begin{array}{l}2.490 \\
\times 1) \\
\end{array}$ \\
\hline
\end{tabular}

Based on the test results obtained by the correlation value of 0.698 means that the quality of service and corporate image simultaneously has a strong relationship to purchasing decisions.

\section{Analysis of the Coefficient of Determination}

Analysis of the coefficient of determination is intended to determine the percentage of influence of the independent variable on the dependent variable either partially or simultaneously. The test results are as follows:

Table 6. Test Results for the Determination Coefficient of Service Quality on Purchasing Decisions

\begin{tabular}{|c|c|c|c|c|}
\hline \multicolumn{5}{|c|}{ Model Summary } \\
\hline Model & $\mathrm{R}$ & R Square & $\begin{array}{l}\text { Adjusted } \mathrm{R} \\
\text { Square }\end{array}$ & $\begin{array}{l}\text { Std. Error of the } \\
\text { Estimate }\end{array}$ \\
\hline 1 & $.635^{\mathrm{a}}$ & .403 & .397 & 2.671 \\
\hline \multicolumn{5}{|c|}{ a. Predictors: (Constant), Quality of service (X1) (X1) } \\
\hline
\end{tabular}

Based on the test results obtained a determination value of 0.403 means that service quality has an influence contribution of $40.3 \%$ to the purchase decision. 
Table 7. Test Results for the Corporate Image Determination Coefficient on Purchasing Decisions

\begin{tabular}{|c|c|c|c|c|}
\hline \multicolumn{5}{|c|}{ Model Summary } \\
\hline $\begin{array}{l}\text { Mode } \\
\text { I }\end{array}$ & $\mathrm{R}$ & R Square & $\begin{array}{l}\text { Adjusted R } \\
\text { Square }\end{array}$ & $\begin{array}{l}\text { Std. Error of the } \\
\text { Estimate }\end{array}$ \\
\hline 1 & $.610^{a}$ & .372 & .366 & 2.739 \\
\hline
\end{tabular}

Source: processed data (2020)

Based on the test results obtained a determination value of 0.372 means that the company's image has an influence contribution of $37.2 \%$ to the purchase decision.

Table 8. Test Results for the Determination Coefficient of Service Quality and Company Image on Purchasing Decisions

\begin{tabular}{lllll}
\hline $\begin{array}{l}\text { Mode } \\
\text { I }\end{array}$ & $\mathrm{R}$ & \multicolumn{2}{c}{ Model Summary } \\
$\mathrm{R}$ Square & $\begin{array}{l}\text { Adjusted } \\
\text { Square }\end{array}$ & $\begin{array}{l}\text { Std. Error of the } \\
\text { Estimate }\end{array}$ \\
\hline 1 & $.698^{\mathrm{a}}$ & .487 & .476 & 2.490
\end{tabular}

a. Predictors: (Constant), Company Image (X2), Quality of Service (X1) Source: processed data (2020)

Based on the test results obtained a determination value of 0.487 means that the quality of service and corporate image simultaneously has an influence contribution of $48.7 \%$ on purchasing decisions, while the remaining $51.3 \%$ is influenced by other factors.

\section{Hypothesis testing}

Hypothesis testing with t-test is used to find out which partial hypotheses are accepted.

First Hypothesis: There is a significant influence between service quality on purchasing decisions.

Table 9. Hypothesis Test Results Service quality on purchasing decisions

\begin{tabular}{|c|c|c|c|c|c|c|}
\hline \multicolumn{7}{|c|}{ Coefficients $^{a}$} \\
\hline \multirow{2}{*}{\multicolumn{2}{|c|}{ Model }} & \multicolumn{2}{|c|}{$\begin{array}{l}\text { Unstandardized } \\
\text { Coefficients }\end{array}$} & \multirow{2}{*}{$\begin{array}{l}\text { Standardized } \\
\text { Coefficients } \\
\text { Beta }\end{array}$} & \multirow[t]{2}{*}{$\mathrm{t}$} & \multirow[t]{2}{*}{ Sig. } \\
\hline & & B & $\begin{array}{l}\text { Std. } \\
\text { Error }\end{array}$ & & & \\
\hline 1 & (Constant) & $\begin{array}{l}17.24 \\
2\end{array}$ & 2.769 & & 6.226 & .000 \\
\hline & $\begin{array}{l}\text { Quality of Service } \\
\text { (X1) } \\
\text { ependent Variable: }\end{array}$ & rchase & .072 & .635 & 7.967 & .000 \\
\hline
\end{tabular}

Based on the test results in the above table, the value of $t$ count $>t$ table or $(7.967>1.986)$ is obtained, thus the first hypothesis proposed that there is a significant influence on the quality of service on purchasing decisions is accepted. 
Table 10. Hypothesis Test Results Corporate image Against purchasing decisions

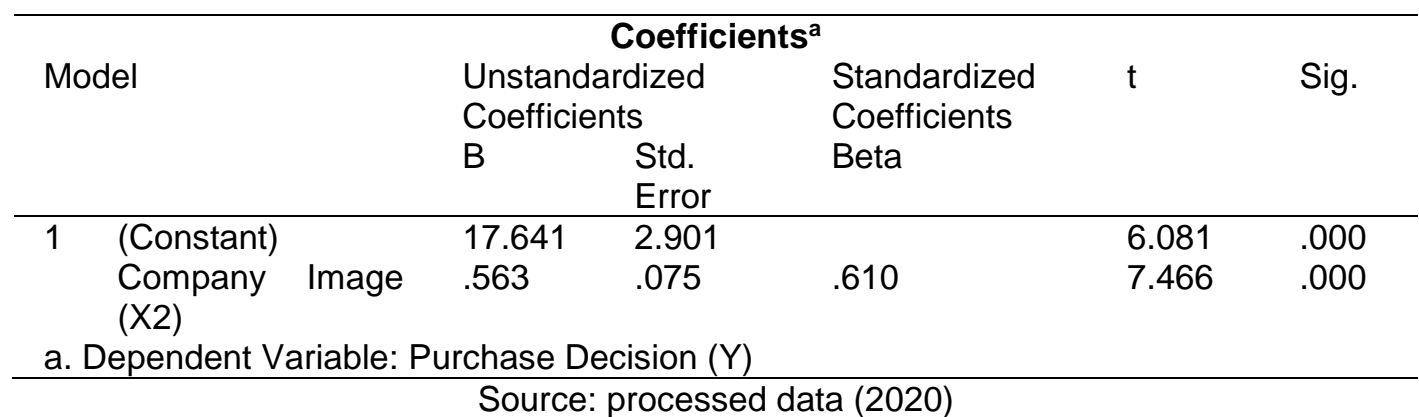

Based on the test results in the above table, the value of $t$ count $>t$ table or $(7.466>1.986)$ is obtained, thus the second hypothesis is proposed that there is a significant influence between the company's image on purchasing decisions accepted.
Hypothesis testing with the $\mathrm{F}$ test is used to find out which simultaneous hypotheses are accepted.

The third Hypothesis There is a significant influence between service quality and corporate image on purchasing decisions.

Table 11. Hypothesis Test Results Service quality and corporate image of purchasing decisions

\begin{tabular}{|c|c|c|c|c|c|c|}
\hline \multirow{2}{*}{\multicolumn{2}{|c|}{ Model }} & \multicolumn{3}{|c|}{ ANOVA $^{a}$} & \multirow[b]{2}{*}{$\mathrm{F}$} & \multirow[b]{2}{*}{ Sig. } \\
\hline & & $\begin{array}{l}\text { Sum of } \\
\text { Squares }\end{array}$ & & Mean Square & & \\
\hline 1 & Regression & 546.685 & 2 & 273.342 & $\begin{array}{l}44.09 \\
1\end{array}$ & $.000^{\mathrm{b}}$ \\
\hline & $\begin{array}{l}\text { Residual } \\
\text { Total }\end{array}$ & $\begin{array}{l}576.555 \\
1123.240\end{array}$ & $\begin{array}{l}93 \\
95\end{array}$ & 6.200 & & \\
\hline \multicolumn{7}{|c|}{$\begin{array}{l}\text { a. Dependent Variable: Purchase Decision }(\mathrm{Y}) \\
\text { b. Predictors: (Constant), Company Image (X2), Quality of Service (X1) }\end{array}$} \\
\hline
\end{tabular}

Source: processed data (2020)

Based on the test results in the above table, the calculated $F$ value $>F$ table or (44.091>2,700), thus the third hypothesis proposed that there is a significant influence between the quality of service and company image on purchasing decisions is accepted.

\section{Effect of service quality on purchasing decisions}

Quality of service has a significant effect on purchasing decisions with a correlation of 0.635 or has a strong relationship with a contribution of $40.3 \%$. Hypothesis testing obtained values of $t$ arithmetic> $t$ table or $(7.967>1.986)$. Thus the first hypothesis proposed that there is a significant effect between service quality on purchasing decisions is accepted.

\section{Influence of company image on purchasing decisions \\ The company's image has a} significant effect on purchasing decisions with a correlation of 0.610 or has a strong relationship with a contribution of $37.2 \%$. Hypothesis testing obtained $\mathrm{t}$ value $>\mathrm{t}$ table or (7.466> 1.986). Thus the second hypothesis proposed that there is a significant influence between the company's image of the purchase decision is accepted.

Effect of service quality and
corporate image on purchasing
decisions
Service quality and company image have a significant effect on purchasing decisions by obtaining a 
regression equation $\mathrm{Y}=11,931+$ $0,380 X 1+0,332 X 2$, a correlation value of 0,698 , or having a strong relationship with a contribution of $48.7 \%$ while the remaining $51.3 \%$ is influenced by factors other. Hypothesis testing obtained $\mathrm{F}$ value $>\mathrm{F}$ table or $(44.091>2.700)$. Thus the third hypothesis proposed that there is a significant effect between service quality and company image on purchasing decisions is accepted.

\section{CONCLUSION}

Quality of service has a significant effect on purchasing decisions with an influence contribution of $40.3 \%$. Hypothesis testing obtained $\mathrm{t}$ value $>\mathrm{t}$ table or (7.967> 1.986). The company's image has a significant influence on purchasing decisions with an influence contribution of $37.2 \%$. Hypothesis testing obtained $\mathrm{t}$ value $>\mathrm{t}$ table or (7.466> 1.986). Service quality and company image have a significant effect on purchasing decisions with a contribution of $48.7 \%$ while the remaining $51.3 \%$ is influenced by other factors. Hypothesis testing obtained the value of $F$ count> F table or (44.091> 2.70 .

\section{REFERENCES}

Kotler, Philip \& Amstrong, Gary. (2016). Dasar-dasar Pemasaran.Jilid 1, Edisi Kesembilan.Jakarta: Erlangga

Kotler, Philip \& Keller, Kevin Lane. (2017). Manajemen Pemasaran, Edisi Keempat Belas. Jakarta: PT. Indeks.

Lupiyoadi. (2017) Manajemen Pemasaran Jasa, Edisi 4. Jakarta: Salemba Empat.

Pujadi, Bambang. (2010). Studi Tentang Pengaruh Citra Merek Terhadap Minat Beli Melalui Sikap Terhadap Merek pada Merek Pasta Gigi Ciptadent di Semarang. Universitas Diponegoro.

Sangadji, E.M., dan Sopiah. (2013). Perilaku Konsumen: Pendekatan Praktis. Disertai: Himpunan Jurnal Penelitian. Yogyakarta: Penerbit
Andi.

Simamora, Henry. (2012). Manajemen Sumber Daya Manusia. Edisi 1. Yogyakarta: STIE YKPN Yogyakarta.

Tjiptono, Fandy. (2017). Service Quality and Satisfaction Edisi tiga. Jakarta: Andi. 